\title{
Dvacet let finančních a bankovních reforem v České republice - pohled z ptačí perspektivy
}

\section{Vážení čtenáři,}

kdo se obával, že konference 20 let finančních a bankovních reforem v České republice, kterou 11. listopadu 2009 uspořádala ve spolupráci s Českou národní bankou Fakulta financí a účetnictví Vysoké školy ekonomické v Praze, bude hlavně nostalgickým, ale i vzpomínkovým optimismem ovlivněným ohlédnutím za minulými lety transformace, byl podle mého názoru př́ijemně překvapen. Tím nechci říci, že nezněla data významných transformačních kroků a př́spěvky, které se minulostí zabývaly. Data a obsahové souvislosti však v zásadě všichni vystupující využili k reálným a leckde i kritickým úvahám o tématech vysoce aktuálních do budoucna.

Věřím, že obsahová náplň konference, která byla svým duchem (a určitě ve prospěch její kvality) spíše pracovní než formálně slavnostní, bude předmětem odborných pojednání bankovních a finančních expertů; rozhodně je co analyzovat. Protože se však odborníkem $\mathrm{v}$ těchto oblastech necítím, chtěl bych se zamyslit nad přínosy konference $\mathrm{v}$ obecnějších souvislostech, které mohou být zajímavé pro všechny z nás, kdo se zabývají řešením našeho fakultního výzkumného záměru Rozvoj finanční a účetní teorie a její aplikace z interdisciplinárního hlediska.

Základním obecným mottem konference byla podle mého názoru skutečnost, že odbornou část našeho života žijeme ve zcela výjimečné době a teritoriu. Nejen časové souvislosti, které nám umožňují zkoumat jednotlivé atributy přechodu od předlistopadových pořádků k vyspělé demokratické společnosti, ale i srovnání se zeměmi, které procházejí obdobným vývojem, a s těmi, k nimž v určitých parametrech vzhlížíme jako ke vzoru, který chceme dosáhnout, vytváŕí obrovský potenciál pro naše nezaujaté, objektivní zkoumání. Bylo v tomto smyslu sympatické, že drtivá většina odborníků, kteří zásadně ovlivňovali vývoj posledních dvaceti let (včetně pana prezidenta), byla ve svých prezentacích upřímná a korektní ve smyslu „,některé věci jsme měli dělat jinak“, „,nedocenili jsme působení toho či onoho faktoru“ a „mýlili jsme se, nebot’ jsme vycházeli z předpokladu, který se nepotvrdil“. Současný odraz světa tak, jak je vytvářen politiky a nám zjednodušeně prezentován medii, vytváří totiž dojem, že přiznat omyl je nepř́ipustné. Toto pravidlo však nemůže platit pro vědecké zkoumání a je dobře, že neplatilo ani na této konferenci.

Objektivita, nezaujatost našeho zkoumání je také spojena s nepsanou uzancí „neznámkovat“ či „nenálepkovat“ jevy na základě jejich vzdálených historických či společenských souvislostí. „Jevy nejsou dobré, či špatné“, prohlásil Vladimír Dlouhý v odpovědi na výhradu, že z jeho příspěvku ne zcela zřetelně vyplývá, zda je pro rychlé přijetí Eura či nikoliv, a pokračoval: ,jsou takové, jaké jsou“, a my je musíme zkoumat ve vzájemných vazbách jejich předností, omezení, prríležitostí a hrozeb“.

Jakkoli bychom tedy měli být „,̌itelní“, co se týče našeho názoru, jde-li od jeho odlišení od názoru alternativního, není couváním z našeho stanoviska i poukaz na jeho rizika a omezení, stejně jako není prohrou připustit, že i alternativní názor má své přednosti. Ve svém zkoumání máme velkou výhodu - nejsme svázáni již realizovanými rozhodnutími: nepřísluší nám - na rozdíl od exekutivy - argumentovat spolu s Miroslavem Kalouskem „,.. je ztrátou 
času diskutovat o přijetí či nepřijetí Eura, protože k jeho přijetí jsme se již zavázali v prrístupové smlouvě“; patří naopak k našim právům a (někdy nepř́ijemným) povinnostem hájit náš názor, a to navzdory skutečnosti, že v dané etapě vývoje už není zdánlivě na pořadu dne, není konformní, převažující nebo formálně vítězící.

Jedna z oblíbených nálepek vyplývá z „nadhledu“, který mají vůči koncepčním úvahám „praktici“. Není tak divu, že i na konferenci zazněla od Richarda Salzmanna (jistě legitimní) poznámka $\mathrm{k}$ názoru Kamila Janáčka na to, zda transformace bank nemohla proběhnout efektivněji; způsob uvedení poznámky, založený na úvaze „takto může přemýšlet teoretik, nikoliv praktik“", však už - navzdory noblese, s jakou byla pronesena - zcela korektní nebyl. $\mathrm{O}$ to přesvědčivější však byla reakce profesora Janáčka, z níž bylo zřejmé, že celý problém vnímá v daleko silnější integritě teorie a praxe, než jak zdánlivě vyplynulo z jeho časově limitované prezentace. Není divu: navzdory „nařčení“ je nejen odborníkem s ohromným vědecko-výzkumným potenciálem, ale také člověkem s úzkou vazbou na praxi, kterou vždy bral jako základní korektiv svých obecných pojednání. Domnívám se, že tato malá epizoda by měla být inspirací i pro nás, kdo v rámci našich vědecko-výzkumných ambicí formulujeme obecně teoretické závěry. V racionálních podmínkách nemůže existovat rozpor mezi teorií a praxí: smyslem našich vědeckých aktivit není konstruovat modely, založené na předpokladech, které se nikdy nenaplní, tím méně rozšíření seznamu našich publikačních výstupů, nutných k dosažení vědecko-pedagogických hodností. Naší hlavní cílovou metou je - stejně jako v jiných oblastech lidského snažení - nalézt ,zákazníka“ - uživatele, kterého obohatíme zhlediska jeho praktických informačních potřeb. Je tak nezbytné, aby náš výzkumný záměr - jakkoli orientovaný na „teorii“ - primárně vycházel z potřeb praxe; to však samožrejmě - mimo jiné - znamená také praxi znát. Teprve v okamžiku, kdy náš koncepční výstup obstojí svým př́inosem v testu praktické aplikace, naplní svůj základní smysl.

Nejen synergie našich teoretických a praktických vědomostí je však dostatečná k dosažení našich vědecko-výzkumných cílů. Jakkoli se naše vědecké zkoumání zdánlivě nepotkává s morálními a etickými aspekty našich osobností, není sporu, že strategicky vyhrávají nejen řešení, která jsou prakticky přínosná a teoreticky obhajitelná, ale také postupy korektní eticky a morálně. Asi nejsilněji tento aspekt zazněl ve vystoupení Martina Mandela, který se sice primárně zamýšlel nad tématem vysoce odborným - nad předpoklady toho, aby měnový kurz byl i nadále spíše stabilizujícím prvkem současné ekonomiky, ale ve výčtu těchto podmínek jako by se obracel k obecnějším vlastnostem jakéhokoliv našeho počínání včetně vědeckovýzkumných aktivit: k základním ,pilírưum“ měnové politiky podle něho patřilo (a tedy mělo by patřit i do budoucna) neměnnost pravidel, dlouhodobá konzistence, snaha o plnění deklarovaných cílů, doprovázená kontinuálním procesem korekcí mezi prognózami a skutečností, transparence, srozumitelnost a poctivost při zveřejňování a analýzách výsledků.

Není sporu o tom, že nejen odbornost, ale zejména výše zmíněné principy přispěly k vývoji směnného kurzu koruny, který je dnes vnímán jako nesporný kladný rys naší transformace. Ta je jistě provázena řadou otázek a problémů, v základních parametrech jde však jistě správným směrem. Jsem přesvědčen o tom, že tyto principy jsou zárukou úspěchu také naší vědecké činnosti - ale nejen jí.

prof. Ing. Bohumil Král, CSc.

člen redakční rady

Českého finančního a účetního časopisu 